\title{
LANDSCAPE
PERFRMANCE
SERIES
}

\section{Sydney Park Water Re-use Project Methods}

\section{Research Fellow(s):}

Catherine Evans MLArch, AB

Senior Lecturer - Landscape Architecture | Built Environment

University of New South Wales

Linda Corkery FAILA RLA ASLA (Intl)

Professor of Landscape Architecture | Built Environment

University of New South Wales

Dr Sara Padgett Kjaersgaard BLArch (hons) AILA RLA

Lecturer - Landscape Architecture | Built Environment

University of New South Wales

\section{Research Assistant:}

Lei Zheng

Master of Landscape Architecture Candidate | Built Environment

University of New South Wales

\section{Firm Liaison:}

Scott Ibbotson

Director

Turf Design Studio

This investigation was conducted as part of the Landscape Architecture Foundation's 2020 Case Study Investigation (CSI) program. CSI matches faculty-student research teams with design practitioners to document the benefits of exemplary high-performing landscape projects. Teams develop methods to quantify environmental, social, and economic benefits and produce Case Study Briefs for LAF's Landscape Performance Series.

To cite:

Evans, Catherine, Linda Corkery, Sara Padgett Kjaersgaard, and Lei Zheng. "Sydney Park Water Re-use Project Methods." Landscape Performance Series. Landscape Architecture Foundation, 2020. https://doi.org/10.31353/cs1671

The full case study can be found at: https://landscapeperformance.org/case-studybriefs/sydney-park 


\section{Table of Contents/Acknowledgements}

We gratefully acknowledge the input and support of the City of Sydney: Jacqui Brooks, Parks Assets and Services Manager; Sophie Golding, Urban Ecology Coordinator; and Damon La'Rance, Project Manager.

For assistance with water quality we are grateful for the input and support of David Knights, Director, Civics (formerly with Equatica); and Simon Lloyd, PhD candidate at UNSW.

\section{Research Strategy}

The overall research strategy is to develop a comprehensive, evidence based study of landscape performance of the Sydney Park Water-Reuse project. The research project offered the opportunity for the researchers to collaborate closely with the design firm liaison, as well as a network of consultants involved in the project's design and construction and stakeholders for example local government agencies. The social performance dimensions of the study provided an opportunity to engage with visitors to the water-reuse project and to understand its impact both within the park and broader neighborhood context.

The research aims to assess the environmental and economic benefits, such as biodiversity, potential cost saving measures, and in particular water quality benefits as the most important elements in relation to the project goals. A multi-method approach is used to calculate these benefits, including reviews of on-site water sampling, analysis of relevant species surveys previously completed, and reviews of construction documentation, government documents, and technical reports. For the social benefits, methods included on-site observation using the Gehl Public Life Toolkit, online visitor/user surveys, and an analysis of social media comments. This triangulated approach provided a balance of qualitative and quantitative data relating to user engagement with the wetland features. All the onsite observation, surveys and interview adhered to local COVID-19 pandemic restrictions in place at the time. 


\section{Environmental Benefits}

\section{Overall Background:}

Hydrological context: Sydney Park is located within the City of Sydney Local Government Area (LGA). This is a highly urbanized area where residential and business/commercial land uses have the highest end user demand. Sydney Park is located within the 108 hectare subcatchment area named 'Alexandra Canal'. This sub-catchment has an estimated run-off of 0.95GL/year which drains southward into the Cooks River and into Botany Bay. The current annual loading of pollutants (specifically, nitrogen, phosphorus and gross pollutants) is extremely high, making the Alexandra Canal one of Sydney's most polluted waterways (GHD 2012).

The stormwater harvesting and re-use system in Sydney Park was constructed in three phases between 2001 and 2015. Phase 1 was built in 2001, Phase 2 in 2011 and Phase 3 in 2015. The system was designed to store and treat 7.5 ML/yr water from the Brickworks Catchment to the northwest; 35ML/yr from neighboring Barwon Park Road; and $750 \mathrm{ML} / \mathrm{yr}$ water pumped from the Munni Channel to the north (Equatica 2014, 3). The Water Reuse Project in this case study is the third and largest phase of the system.

Improves water quality in the wetlands by increasing the number of instances when water samples meet local guidelines. Between 2012 and 2016, 3 out of the 4 wetlands improved in microbial water quality. Increases ranged from $6 \%$ to $49 \%$ in the number of water samples meeting local criteria for good to fair quality.

\section{Background:}

It can be challenging to optimise biofilter design for a wide range of pollutants. For example, at Sydney Park, water quality is affected by microbial contaminants as well as chemicals and heavy metals carried by stormwater runoff and leachates. Nonetheless, Sydney Park is a significant site to test microbial performance as it is one of the few constructed wetlands in Sydney where there is opportunity for contact with water-at the stepping stones in the Cascades, as well as the eastern edge of Wetland 4.

Our aim was to assess the change in water quality pre and post construction, as measured against the Australian National Health and Medical Research Council (NHMRC) guidelines. We selected enterococci as an indicator of microbial performance and changes in the risk to public health and compared sampling results with NHMRC guidelines to assess when and where the system has met acceptable levels for freshwater ecosystems. We also calculated the percentage of improvement towards acceptable levels over time.

\section{Method:}

- Because the City of Sydney has been monitoring water quality in the Sydney Park wetlands, we used their reports. The City contracts consultants to undertake the sampling and reporting, and we note that two different consultants did this work between 2012 and 2016.

- We reviewed the results of water quality sampling for public recreational health 
undertaken by the City of Sydney and tabulated the frequency or number of days each wetland and the overall system met the NHMRC Guidelines (Table 1, Table 2).

- We used the median values for our calculations.

- We simplified the data by clustering the good and fair samples as one category and the poor and bad samples as a second category. (Table 3)

- The total number of samples collected in 2012 and 2016 varied over time. For example, 18 samples were collected from Wetland 1 in 2012 and 12 in 2016 . This made it impossible to compare numbers or frequency of samples. Instead, we assessed the change based on the percentage of good to fair/poor to bad samples in 2012 and 2016 (Table 3).

- To explore the question of whether or not one wetland is healthier than the others, we also assessed the overall health of each wetland, over the entire period of time for which we had data. These results are shown in Tables 4 and 5. This demonstrates that overall the wetlands are mostly healthy and safe for recreational contact. Wetlands 1 and 5 seemed to be slightly healthier than Wetlands 2 and 4 .

Table 1. Enterococci Sampling Results as frequency of samples meeting range of NHMRC water quality guidelines by wetland from 2012-2016. Water sampling data provided by the City of Sydney.

\begin{tabular}{|c|c|c|c|c|c|c|c|c|c|c|c|c|c|c|c|c|c|c|c|c|c|}
\hline \multirow[b]{2}{*}{ Water body } & \multirow[b]{2}{*}{ Total } & \multicolumn{4}{|c|}{2012} & \multicolumn{4}{|c|}{2013} & \multicolumn{4}{|c|}{2014} & \multicolumn{4}{|c|}{2015} & \multicolumn{4}{|c|}{2016} \\
\hline & & A & B & C & D & A & B & C & D & A & B & C & D & A & B & C & D & A & B & C & D \\
\hline Wetland 1 & 72 & 14 & 3 & 1 & 0 & 2 & 3 & 3 & 4 & 0 & 0 & 3 & 3 & 18 & 5 & 1 & 0 & 9 & 3 & 0 & 0 \\
\hline Wetland 2 & 84 & 7 & 10 & 1 & 0 & 5 & 9 & 2 & 8 & 0 & 0 & 1 & 5 & 0 & 16 & 4 & 4 & 9 & 3 & 0 & 0 \\
\hline Wetland 4 & 140 & 11 & 1 & 1 & 5 & 6 & 7 & 4 & 7 & 1 & 1 & 3 & 21 & 35 & 12 & 0 & 1 & 23 & 1 & 0 & 0 \\
\hline Wetland 5 & 96 & 12 & 6 & 0 & 0 & 11 & 7 & 0 & 6 & 5 & 3 & 2 & 8 & 11 & 8 & 5 & 0 & 12 & 0 & 0 & 0 \\
\hline total & 392 & 44 & 20 & 3 & 5 & 24 & 26 & 9 & 25 & 6 & 4 & 9 & 37 & 64 & 41 & 10 & 5 & 53 & 7 & 0 & 0 \\
\hline
\end{tabular}

frequency of samples meeting guideline values, per wetland, per year in Sydney Park

Table 2. NHMRC Criteria for Enterococci

\begin{tabular}{|c|c|}
\hline $\begin{array}{c}\text { NHMRC } \\
\text { microbial } \\
\text { categories }\end{array}$ & $\begin{array}{r}\text { Enterococci } \\
\text { (cfu/100mI) }\end{array}$ \\
\cline { 1 - 1 } A 'Good' & $41-40$ \\
\cline { 1 - 1 } B 'Fair' & $201-500$ \\
\hline C 'Poor' & $501+$ \\
\hline D 'Bad' & \\
\hline
\end{tabular}


Table 3.

Percent overall improvement of quality of water from 2012 to 2016 by wetland and in terms of microbial performance. Water sampling data provided by the City of Sydney.

\begin{tabular}{|c|c|c|c|c|c|c|c|}
\hline $\begin{array}{l}\text { Sydney Park } \\
\text { Enterococci } \\
\text { sampling } \\
\text { results } \\
2012 \text { \& } 2016\end{array}$ & $\begin{array}{l}2012 \mathrm{~N} \\
\text { umber of } \\
\text { samples }\end{array}$ & $\begin{array}{l}\% \text { good to } \\
\text { fair }\end{array}$ & $\begin{array}{l}\text { \% bad to } \\
\text { poor }\end{array}$ & $\begin{array}{l}2016 \\
\text { Number of } \\
\text { samples }\end{array}$ & $\begin{array}{l}\% \text { good to } \\
\text { fair }\end{array}$ & $\begin{array}{l}\text { \% bad to } \\
\text { poor }\end{array}$ & $\begin{array}{l}\begin{array}{l}\text { Overall } \\
\text { improvement } \\
\text { (percentage) }\end{array} \\
\text { 2012-2016 }\end{array}$ \\
\hline Wetland 1 & 18 & $94 \%$ & $6 \%$ & 12 & $100 \%$ & $0 \%$ & $6 \%$ \\
\hline Wetland 2 & 18 & $94 \%$ & $6 \%$ & 12 & $100 \%$ & $0 \%$ & $6 \%$ \\
\hline Wetland 4 & 18 & $67 \%$ & $33 \%$ & 24 & $100 \%$ & $0 \%$ & $33 \%$ \\
\hline Wetland 5 & 18 & $100 \%$ & $0 \%$ & 12 & $100 \%$ & $0 \%$ & $0 \%$ \\
\hline
\end{tabular}

Calculations for percent change in water quality as shown in Table 3

For each wetland, for each year we calculated:

- The number of samples meeting criteria for good and fair water quality by adding columns A and B from Table 1. We labelled this sum as follows: Ng Wtind1 (2012)

- The number of samples meeting criteria for bad to poor water quality by adding columns C and D from Table 1. We labelled this sum as follows: Np Wtind 1 (2012)

- The percentage of samples meeting criteria for good and fair water quality as $\mathrm{Ng}(2012) / \mathrm{Nt}(2012)$

- The percentage of samples meeting criteria for bad to poor water quality as $\mathrm{Np}(2012) / \mathrm{Nt}$ (2012)

Where: 
- $\mathbf{N t}=$ Total number of samples per wetland, per year as noted in parentheses

- $\mathbf{N g}=$ number of samples meeting NHMRC criteria for good and fair water quality, per wetland per year as noted in parentheses

- $\mathbf{N p = n u m b e r ~ o f ~ s a m p l e s ~ m e e t i n g ~ N H M R C ~ c r i t e r i a ~ f o r ~ p o o r ~ w a t e r ~ q u a l i t y , ~ p e r ~ w e t l a n d ~ p e r ~}$ year as noted in parentheses

To calculate the overall improvement as a percentage, we subtracted the percent of good/fair samples in 2012 from the percent of good/fair samples in 2016. We divided this by the number of good/fair samples in 2012.

We were interested to find out if and to what extent health varies from wetland to wetland across the entire period. Is one wetland healthier than the others? For this we summarised sampling results across the entire period and again consolidated the categories of health from four to two, setting up a binary of good/bad quality.

Table 4. Summary of Enterococci Sampling Results 2012-2016 as frequency of samples meeting range of $\mathrm{NHMRC}$ water quality guidelines.

\begin{tabular}{|l|r|r|r|r|r|}
\hline & & \multicolumn{5}{|c|}{ Microbial categories 2012-2016 } \\
\hline Water body & no samples & A & B & C & D \\
\hline Wetland 1 & 72 & 43 & 14 & 8 & 7 \\
\hline Wetland 2 & 84 & 21 & 38 & 8 & 17 \\
\hline Wetland 4 & 140 & 76 & 22 & 8 & 34 \\
\hline Wetland 5 & 96 & 51 & 24 & 7 & 14 \\
\hline total & 392 & 191 & 98 & 31 & 72 \\
\hline
\end{tabular}

Table 5. Summary of Enterococci Sampling Results 2012-2016 as frequency of samples meeting range of NHMRC water quality guidelines, simplified.

\begin{tabular}{|l|r|c|c|c|c|}
\hline & & \multicolumn{3}{|c|}{ Microbial categories 2012-2016 } \\
\hline Water body & no samples & \multicolumn{2}{|c|}{ Good/fair } & \multicolumn{2}{c|}{ poor /bad } \\
\hline & & $\#$ & $\%$ & $\#$ & $\%$ \\
\hline Wetland 1 & 72 & 57 & 79 & 15 & 21 \\
\hline Wetland 2 & 84 & 59 & 70 & 25 & 30 \\
\hline Wetland 4 & 140 & 98 & 70 & 42 & 30 \\
\hline Wetland 5 & 96 & 75 & 78 & 21 & 22 \\
\hline total & 392 & 289 & 74 & 103 & 26 \\
\hline
\end{tabular}

Calculations for Tables $\mathbf{4}$ and 5, summary of sampling results across the entire period: We found the sum total of good/fair samples for each wetland and divided this by the total number of samples taken between 2012-2016 to find the percentage of samples which were $\mathrm{good} / \mathrm{fair}$ for each wetland. We repeated this for the poor/bad results. 


\section{Sources:}

- Australia New Zealand Group. (2018). Australian and New Zealand guidelines for fresh and marine water quality. Australian and New Zealand Governments and Australian state and territory governments, Canberra ACT, Australia. Available at www.waterquality.gov.au/anz-guidelines

- Australian National Health and Medical Research Council. (2008.) Guidelines for Managing Risks in Recreational Water. Available at https://www.nhmrc.gov.au/aboutus/publications/guidelines-managing-risks-recreational-water

- Brooks, Jacqui. ( 2020) Personal communication (email).

- Equatica. (2014). Sydney Park stormwater treatment and harvesting system: Operations and Maintenance Plan.

- GHD Lakes \& Wetlands Monitoring for Sydney Park (GHD Report: 23/15288) 20142017. Provided by the City of Sydney.

- GHD (2012) City of Sydney Decentralised Water Master Plan: WSUD \& Stormwater Infrastructure Report. GHD for the City of Sydney.

\section{Limitations:}

- These calculations for microbial contamination do not account for wet weather events.

- The calculations for this method have not been reviewed by the City of Sydney.

- We had a limited range of data, only through 2016. Samples for a longer range of time (through to 2018 or 2020) would allow for a more complete longitudinal study and would allow clearer evidence of cause and effect relationship between the Water Re-Use and Harvesting Project and water quality.

Improves water quality in wetland 4 with a $68 \%$ reduction in copper, $50 \%$ reduction in nickel, $85 \%$ reduction in nitrogen, and $68 \%$ reduction in zinc, meeting local guidelines for water quality. Because wetland 4 receives water from wetland 1 and 2, improved water quality there suggests that the bioretention cells introduced in the wetlands as part of the Water Re-use Project are effective. 
Table 6. Reduction in median nutrient loading in Wetland 4, 2012-2016. Water Sampling data provided by the City of Sydney.

\begin{tabular}{|l|r|r|r|r|r|r|r|r|}
\hline & $\begin{array}{l}\text { difference } \\
\text { 2012-2016 }\end{array}$ & $\begin{array}{l}\text { percentage } \\
\text { reduction }\end{array}$ & $\begin{array}{r}\mathbf{2 0 1 2} \\
\text { median }\end{array}$ & $\begin{array}{r}\mathbf{2 0 1 3} \\
\text { median }\end{array}$ & $\begin{array}{r}\mathbf{2 0 1 4} \\
\text { median }\end{array}$ & $\begin{array}{r}\mathbf{2 0 1 5} \\
\text { median }\end{array}$ & $\begin{array}{r}\mathbf{2 0 1 6} \\
\text { median }\end{array}$ & $\begin{array}{l}\text { ANZECC } \\
\text { Guidelines }\end{array}$ \\
\hline Copper & 0.0048 & $68 \%$ & 0.0071 & 0.0139 & 0.0172 & 0.0042 & 0.0023 & 0.0025 \\
\hline Nickel & 0.001 & $50 \%$ & 0.002 & 0.005 & 0.006 & 0.002 & 0.001 & 0.017 \\
\hline Nitrogen & 3.5 & $85 \%$ & 4.1 & 1.7 & 2.4 & 1.1 & 0.6 & 0.5 \\
\hline Zinc & 0.013 & $68 \%$ & 0.019 & 0.056 & 0.039 & 0.01 & 0.006 & 0.031 \\
\hline
\end{tabular}

\section{Method:}

Here we were interested to know how much the nutrient loading changed over time, with reference to the Australian and New Zealand Environment and Conservation Council (ANZECC) guidelines.

- As above we used the water sampling data and reports prepared by consultants to the City of Sydney to tabulate the concentration of nutrients and particles in each wetland between 2012 and 2016

- The data was tabulated by year and includes the minimum, maximum, median and mean amounts for each category.

- The median level of concentration was used for our calculations.

- We reviewed the tables line by line, element by element to identify patterns, degree of change, and inconsistencies with the data.

- We omitted from our assessment nutrients and particles where sampling was incomplete either for a wetland and/or a particle type.

- Using this method, we identified Wetland 4 as the only wetland with a consistent data set.

\section{Calculations:}

- We determined the difference between 2016 and the 2012 concentrations to find the amount of change by mass ( $\mathrm{mg} / \mathrm{L})$. We divided this difference by the 2012 amounts to determine the percentage increase for particle/nutrient type.

\section{Sources:}

Australia New Zealand Group. (2018). Australian and New Zealand guidelines for fresh and marine water quality. Australian and New Zealand Governments and Australian state and territory governments, Canberra ACT, Australia. Available at www.waterquality.gov.au/anz- 
guidelines

Australian National Health and Medical Research Council. (2008.) Guidelines for Managing Risks in Recreational Water. Available at https://www.nhmrc.gov.au/aboutus/publications/guidelines-managing-risks-recreational-water

Brooks, Jacqui. (2020). Personal communication (email)

Equatica. (2014). Sydney Park stormwater treatment and harvesting system: Operations and Maintenance Plan.

GHD Lakes \& Wetlands Monitoring for Sydney Park (GHD Report: 23/15288) 2014-2017. Provided by the City of Sydney.

\section{Limitations:}

- Water sampling was incomplete for the entire system during this time period. In some cases samples were missing for either one or more particle types or one or more of the wetlands. We thus have an incomplete picture of changes in ecosystem health.

- Constraints in the water harvest offtake system meant that storm flows are not captured and treated by the system across the entire period of sampling. Thus the results reflect the system working in a limited rather than full capacity.

- Quarterly reports prepared by GHD between 2012 and 2019 use a range of methods.

- The calculations for this method have not been reviewed by the City of Sydney.

- We had a limited range of data, only through 2016. Samples for a longer range of time (through to 2018 or 2020) would allow for a more complete longitudinal study and would allow clearer evidence of cause and effect relationship between the Water Re-Use and Harvesting Project and water quality.

\section{Supported a 24\% increase in the number of bird species recorded from 2013 to 2019 with new habitat areas, with a 5.21-acre or 119\% increase in Sydney freshwater wetlands habitat and the addition of 0.95 acres of gully forest habitat.}

\section{Method:}

Percentage increase in native plant species type (in Features)

- A 2010 Flora survey undertaken by the City of Sydney was used to determine the species present within the wetland areas prior to construction. These plants were tabulated into an excel document to determine the number and type of plant species prior to construction. See Table 7.

- We used two approaches to determine the species post-construction. First, we tabulated the species of plants from the planting schedule in the construction documentation. We cross-referenced this information with a 2017 flora survey undertaken by the City of Sydney to ensure we were capturing plants that had survived the post-construction period as some plant species loss is usually anticipated. We refined the initial tabulated species from the construction documentation to include only those plant species that appeared in both the construction documentation and the flora survey. We then 
calculated the difference between the total number of species before and after construction and determined the species increase across this period.

- There were a total of 57 new species identified in the Planted Gully Forest from an original 32 species, for a total of 89 species. Some 73 new species were identified in the Planted Sydney Freshwater Wetlands from an original 66 species, for a total of 139 plant species.

\section{Percentage increase in bird species}

- Not-for-profit organisation Bird Life Australia operates a national bird data database that relies on both specialized professional knowledge and citizen science participation. The database has compiled an extensive amount of bird data from across the continent. Sydney Park is a well-studied site and a large amount of data on bird species was available for interpretation by the researchers and used for this case study. Furthermore, the data is publicly available, which encourages ongoing observation and study of this performance metric by the research team after the LAF case study is completed.

- We identified 22 sites in total around the wetlands, where there was sufficient bird counting data recorded before construction (2013-2015) and post-construction (20152019). We extracted the data for each site. This included latitude and longitude; bird survey number; date; type of survey; and bird species identified. In total, the data for 88 individual bird surveys, across 22 sites, from the 2013-2019 year period were extracted, tabulated and compared.

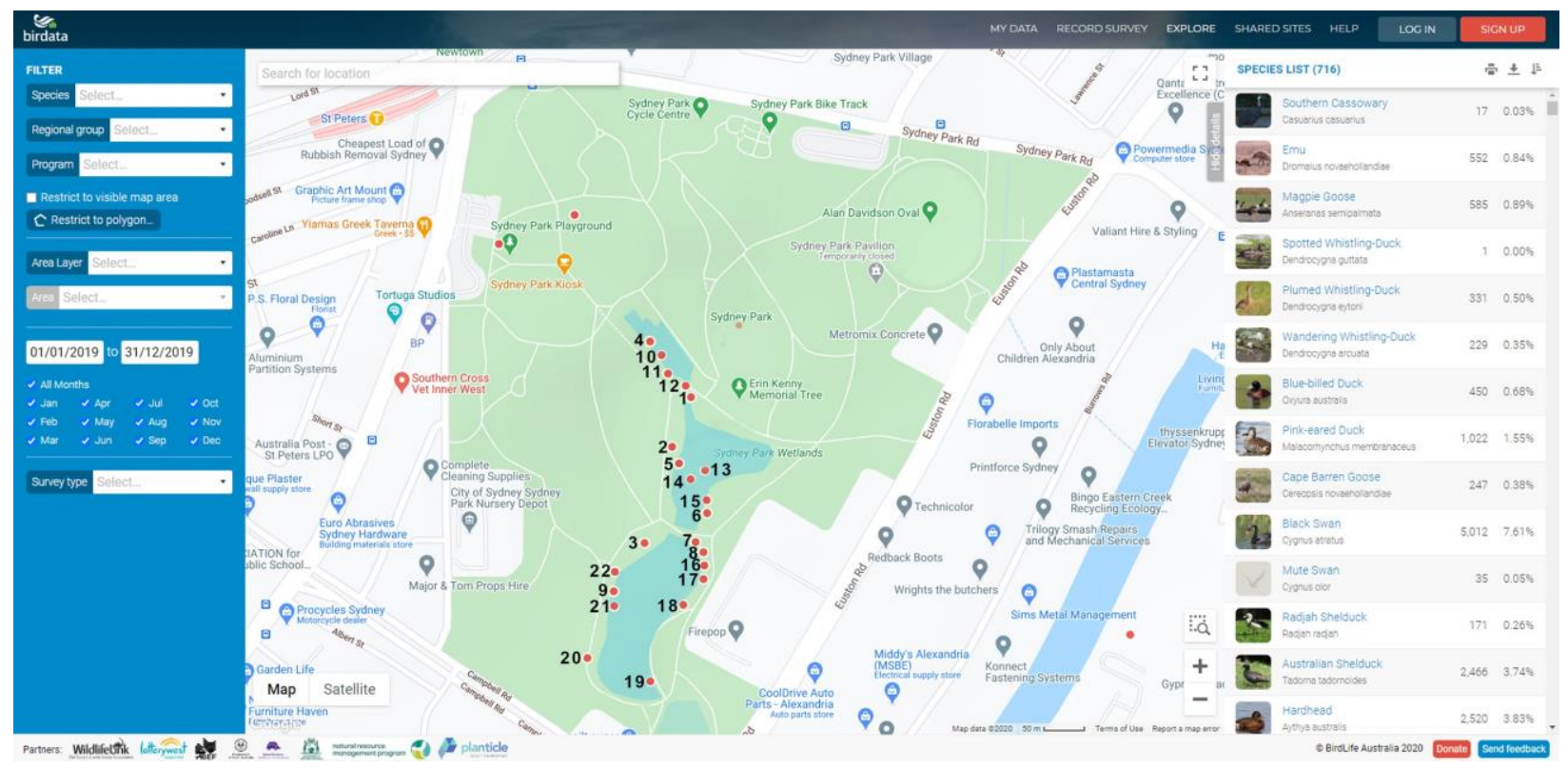

Figure 1: Map of bird-species data collection sites within Sydney Park 
Table 7: A screenshot of bird species data tabulated in Excel for each observation site.

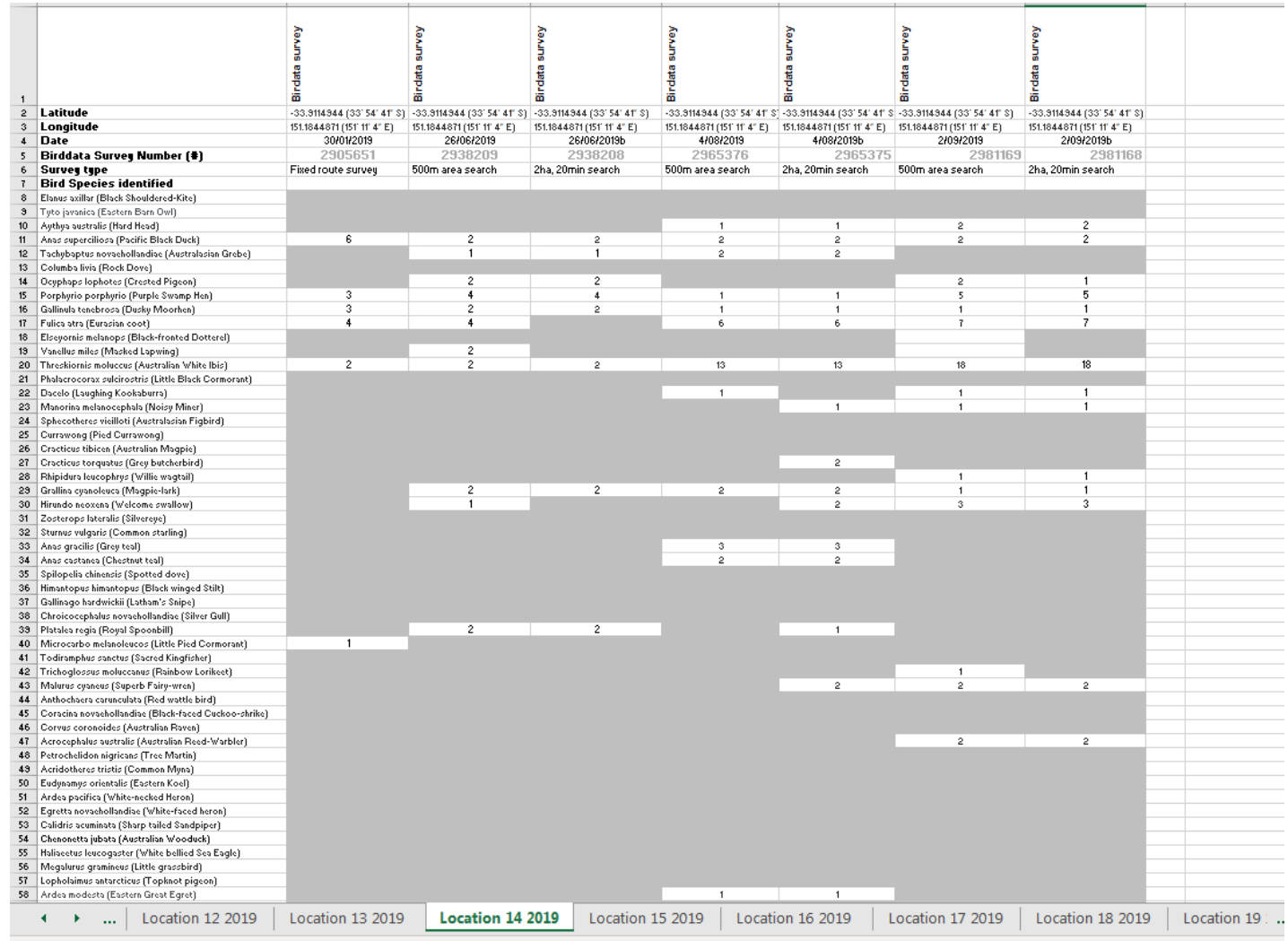

- A total of 58 individual bird species were identified in the data from surveys conducted before construction of the Sydney Park water recycling project. A total of 74 individual bird species were identified in the data from surveys conducted after the construction of the project in 2015.

\section{Calculations:}

- Planted Gully Forest: 89 species in total / 32 original species $=2.78125$

Convert to a \%. $2.78125 \times 100=278 \%$

Subtract $100 \%=178 \%$ increase in species

Planted Gully Forest: Pre construction 2013 area $=0$. Post construction 2017 area $=41$, $333 \mathrm{sf} / 0.95$ acres.

- Planted Sydney Freshwater Wetlands: 139 species in total / 66 original species $=2.1060$ Convert to a \% 210.606

Subtract $100 \%=110 \%$ increase in species

- Planted Sydney Freshwater Wetlands: Pre construction 2013 area = 4.36 acres. Post construction 2017 area $=9.57$ acres. To find the percentage increase 9.57/4.36 $=2.194$. Convert to a $\%(x 100)=219.377$. Subtract $100 \%=119 \%$ increase in planted areas.

\section{Sources:}

- Birdlife Australia. Budding Birdos 2019 Final Report for City of Sydney January 2020, Birdlife Australia, 2020.

- Birdlife Australia, “Live Map Data.” Accessed June 13, 2020. 
https://birdata.birdlife.org.au/

- City of Sydney. Flora surveys 2010-2017 (spreadsheets provided via Jacqui Brooks, via email)

- City of Sydney. (2020). Urban Ecology Strategic Action Plan. Sydney. https://www.cityofsydney.nsw.gov.au/ data/assets/pdf file/0011/198821/2014-109885Plan-Urban-Ecology-Strategic-Action-Plan FINAL- adopted.pdf

- City of Sydney. (2018). "Bioblitz in Sydney Park." Last modified April, 2018. https://www.inaturalist.org/projects/bioblitz-in-sydney-park

- NearMap Australia Pty Ltd. https://nearmap.com

- City of Sydney. (2017). Flora Surveys for the City of Sydney Council. Sydney. See "Table 1 - Vegetation communities identified during the survey," (p.8); "Table 2 Changes in the extent of vegetation communities at each site" (p.12); "Table 3 - Number of Indigenous species recorded at each site during this survey compared to baseline survey" (p.13).

\section{Limitations:}

- Only one hand-written flora survey prior to construction is available for comparison. This is a limited data-set and is from the year 2010. It is possible that there could have been changes to the flora profile of the wetlands between 2010-2014 prior to construction commencing that the research team are unaware of.

- The City of Sydney flora survey (2010) is not publicly available.

- Wetland data has not been field checked by the research team but was completed by the COS ecologist.

\section{Social Benefits}

We took a triangulated approach to assessing the social benefits. Triangulation was used to ensure biases from using a single method were overcome and to enhance the credibility and rigor of the study. We found this to be of greater importance in 2020 due to the limitations placed on the research team due to the COVID-19 pandemic.

Communicates the water story of the park through environmental artwork, titled "Water Falls," with 95\% of the 21 surveyed visitors indicating they would make a point of showing it to a visitor to the park. A total of 766 visitors, or $27 \%$ of visitors during the observation period, were observed interacting with "Water Falls" through passive activities such as stopping to admire it, discussing it with others, and taking photos.

\section{Method:}

We wanted to determine how effectively the environmental artwork feature communicated the water story of the Sydney Park water-reuse project to park users. We used three approaches to collecting data that would help us determine this: a survey questionnaire, on-site observations and an assessment of social media posts tagging the artwork.

On-line survey questionnaire: Due to the physical distancing restrictions brought about by the COVID-19 pandemic, we created an online questionnaire that could be distributed through local 
community networks. We constructed the questionnaire using two methods. First, for eight of the eleven questions, we used a five-point Likert scale method with the choices ranging from Strongly Agree (rated 5) to Strongly Disagree (rated 1). A neutral option of Neither Agree nor Disagree (rated 3) was offered. Question 5 allowed participants to select multiple answers. For this question the $(n)$ value was determined against each response. The remaining three questions were closed-questions designed to gauge the participants' responses to statements about the environmental artwork the research team had hypothesised.

We used experience management software Qualtrics XM to format the survey questions. We decided on Qualtrics XM because the university had a licence and the data is securely stored. Qualtrics XM is an easy platform to use and collecting survey data digitally was new to the research team. We contacted the administration of two local community Facebook groups (Erskineville and Newtown) to request distribution to the group members. Erskineville and Newtown are two of the suburbs adjacent to Sydney Park's boundary. The survey was posted online in the discussion thread of the Erskineville and Newtown Facebook groups. We received 21 completed unique questionnaire responses. We used the Qualtrics XM reporting function to tabulate the data.

On-site observation: On-site observation is a means of generating data that allows researchers to be in a defined location collecting data while also being part of the scene. We adapted the Gehl Institute's Public Life Data Protocol "People Moving Count" for our purposes (https://gehlpeople.com/tools/people-moving-count/), and carried out an abbreviated version within the scope of time and resources available to us.

We decided on using this research method because:

- it is relatively simple to organize and uncomplicated to learn

- it is an unobtrusive way to observe people's use of public space

- it enables researchers to be objective in their work and not influence or interfere with people as they're going about their activities

We picked two weekdays to undertake the on-site observations. On the first day (September 17 2020), we observed people from $10 \mathrm{am}$ to $2 \mathrm{pm}$. The weather was warm, with a temperature ranging from 80-84 degrees $\mathrm{F}$, light clouds and a soft breeze. On the second day (October 22 2020), we observed people from $10.15 \mathrm{am}$ to $12 \mathrm{pm}$. The weather was mild to warm, with a temperature of 68 degrees $F$, overcast and a soft breeze. 


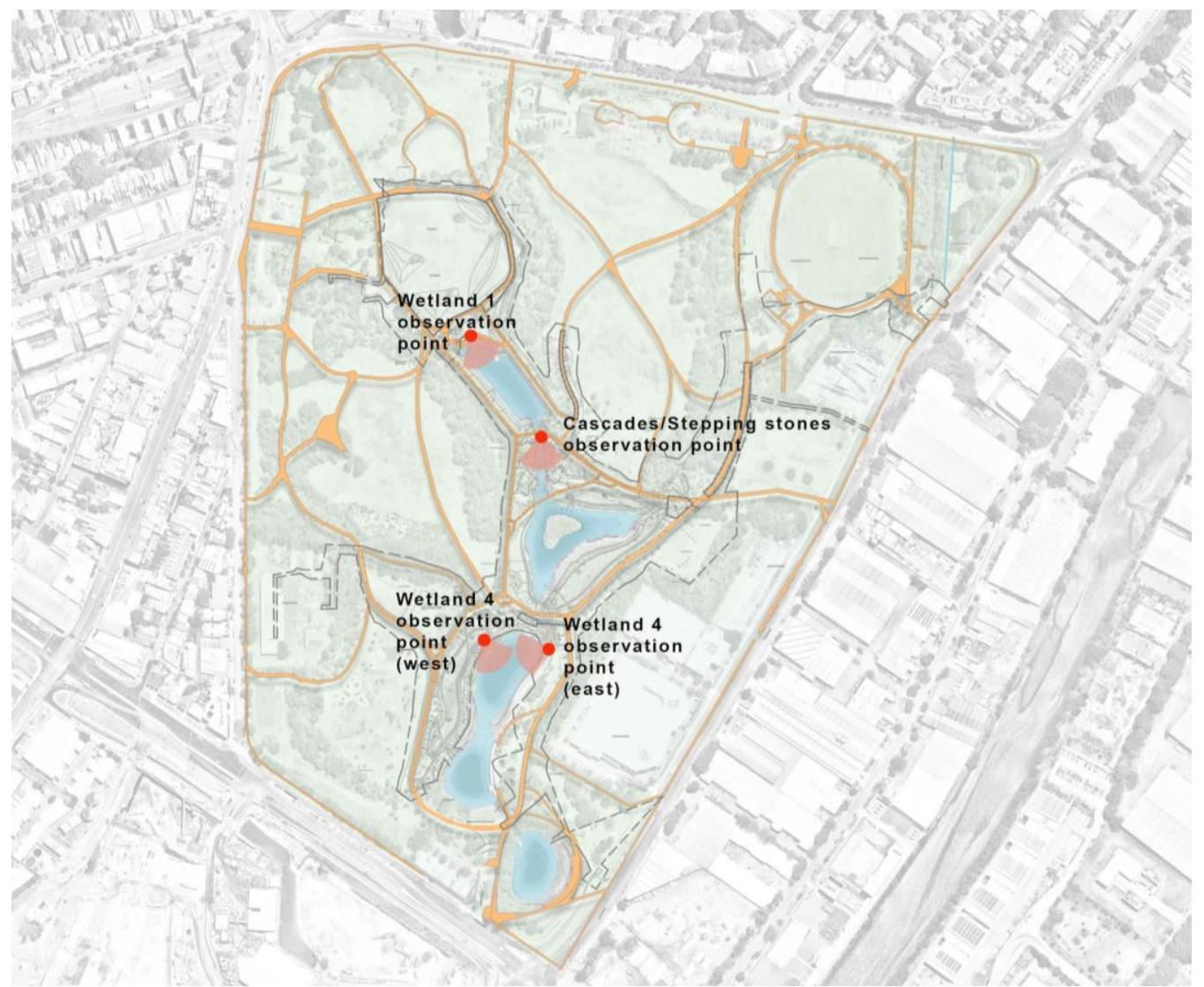

Figure 2: Observation areas for the 'People Moving Count'

The observation activities were carried out to observe human movement, behaviors and activities occurring within the water reuse project area and those areas directly adjacent to it. We paid particular attention to any activity relating specifically to the Water Falls, Cascades and Stepping Stone design features of the constructed water reuse project. When observing people we recorded:

- the circulation routes taken

- the numbers of people observed and their general locations

- the numbers of dogs in attendance with owners

- what people were doing, e.g. walking, running, sitting, interacting with the water, looking for birds, reading the interpretive signage, etc.

- general categories of visitors, e.g. "adults" v. "kids"; having decided that gender and/or age were not relevant concerns for this research.

Observations were recorded on a base plan that had been designed for each of the specific four locations. Observers noted the date, time, weather conditions, their location in the area, simple counting marks, and any additional notes. 


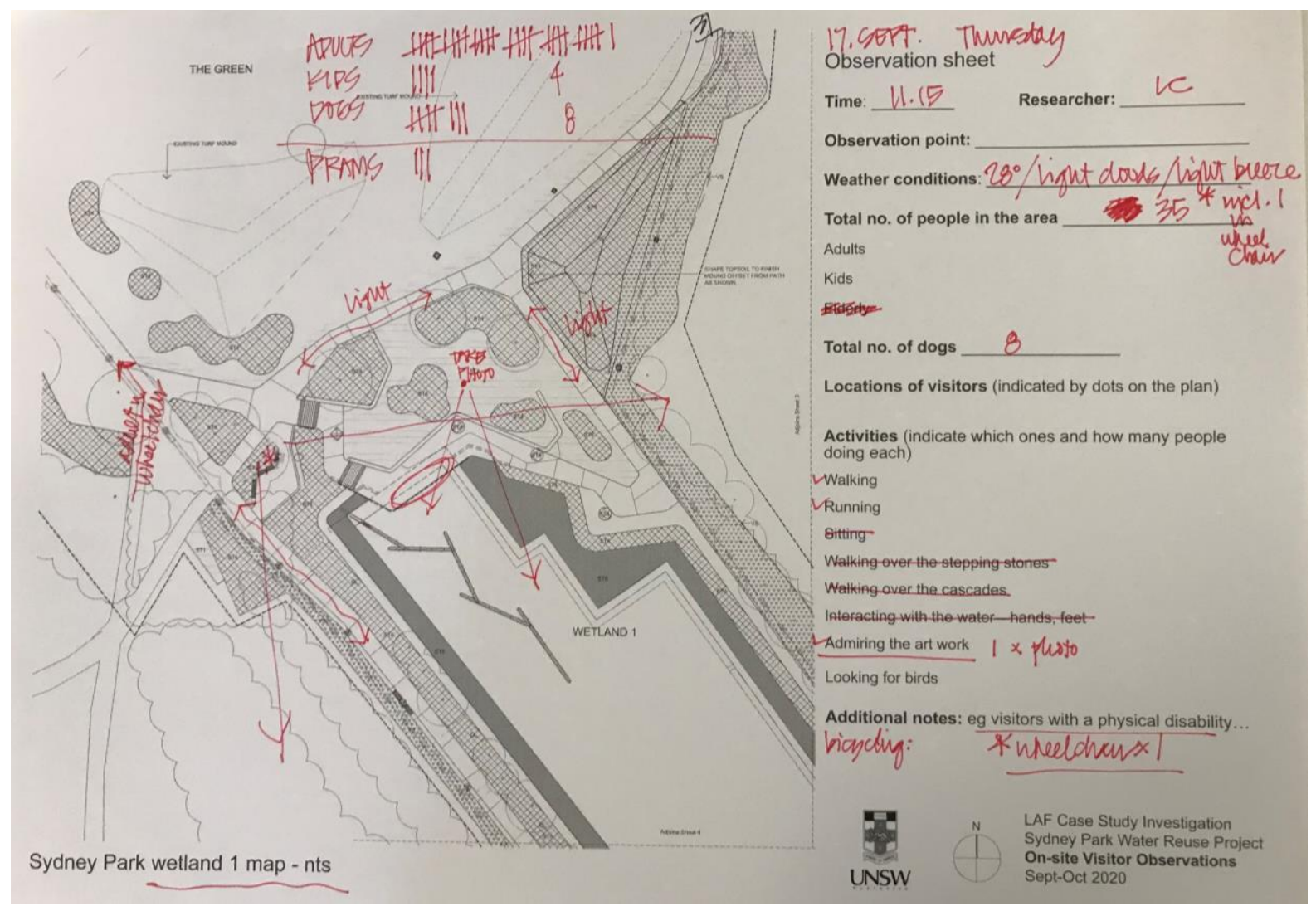

Figure 3: Example of a on-site Visitor Observation sheet for Sydney Park - side A 


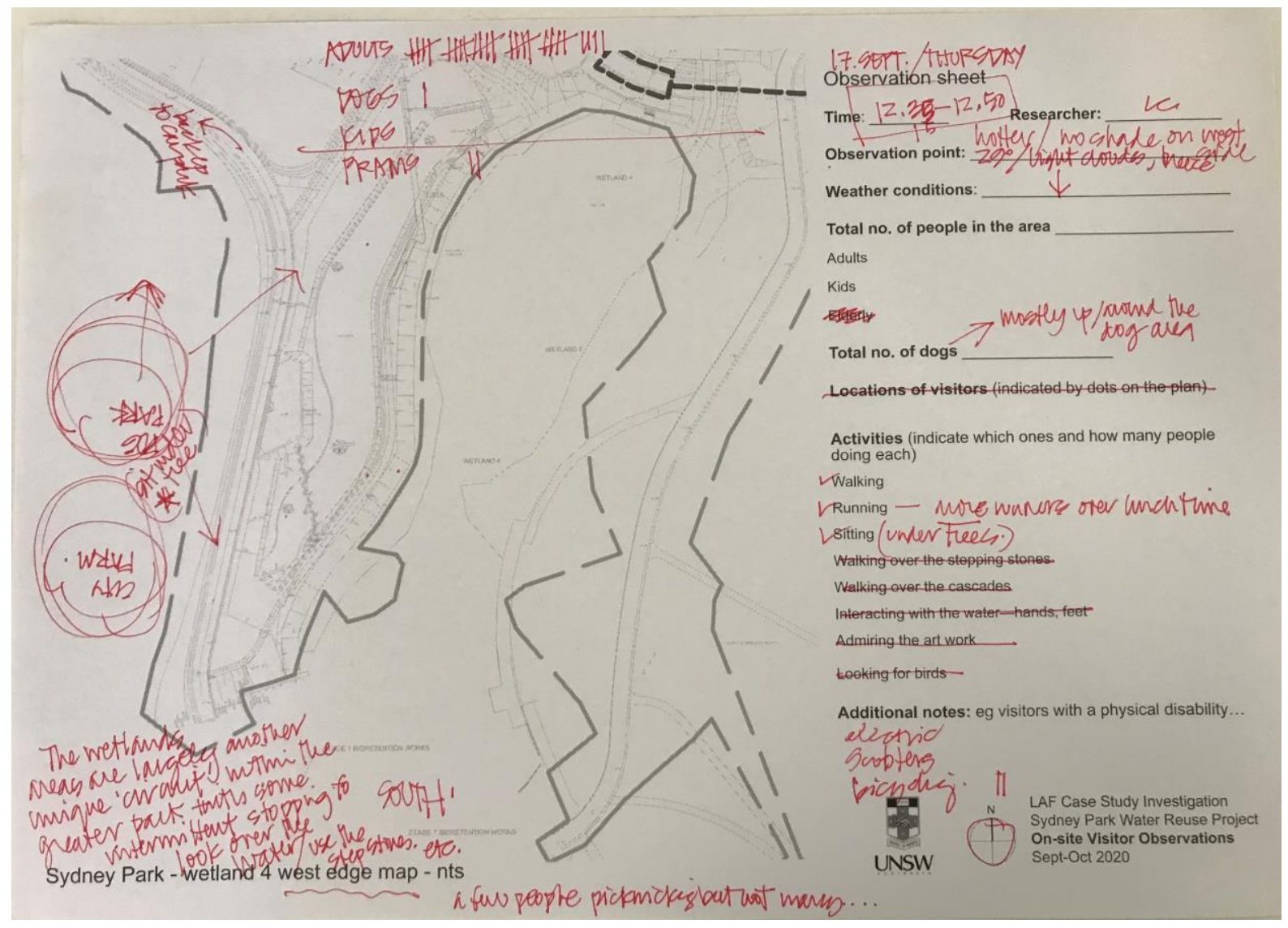

Figure 4: Example of a on-site Visitor Observation sheet for Sydney Park - side B

Observers recorded their findings over 15-minute blocks of time and generally stayed in one location for 1.5-2.0 hours. In total, there were 31 observation records, with 766 people and 201 dogs observed. Of the 766 people, 100 were kids.

The individual observations were tabulated to determine the number of adults, kids and dogs observed at each site. While the main activities observed were walking and running across both days, several other activities were identified and included in the table.

\section{On-site Observation:}

A total of 31 individual observation sheets were completed across the two observation periods in September and October. The following table provides a summation of the combined numbers of the 'People Moving Count' and 'Stationary Activity Mapping' observation exercise for each observation area on each day. 
Table 8: Sydney Park Observations: Thursday September 172020

Sydney Park Water Re-use Project: on-site observations

Thursday, Sept 17, 2020 from 10am-2pm

L Corkery and L Zheng, in four locations around the lower park

Light clouds, soft breezes, temp ranged from $80-84$ degrees $F$

\begin{tabular}{|l|r|r|r|}
\hline \multicolumn{1}{|c|}{ Area } & \multicolumn{2}{|c|}{ Adults } & \multicolumn{2}{c|}{ Kids } \\
\hline Wetland Area 1 & 172 & 21 & 32 \\
\hline Wetland 4 (West side) $^{*}$ & 141 & 5 & 13 \\
\hline Wetland 4 (East side) $^{*}$ & 157 & 13 & 20 \\
\hline Cascades/Stepping stones & 143 & 30 & 59 \\
\hline TOTALS & $\mathbf{4 8 6}$ & $\mathbf{6 9}$ & $\mathbf{1 2 4}$ \\
\hline
\end{tabular}

Main activity observed

- Walking and Running

Other activities observed

- Bicycling: On this day, 30 people, or $6 \%$ of visitors were on bikes

- Taking photos of the site, self, each other, of birds, artwork or site features

- Interacting with water, eg on the stepping stones.

- 1 person in wheelchair, 1 other noted with disability.

- 2 people on electric scooters.

- $\quad$ Sitting: more prevalent in Wetland 4 area as there are tables and benches provided here.

- In total 25 prams were observed. **

*It's very likely that some of these were double-counted as people were walking around the wetland pathway.

This was also a longer period of time for observations

**only noted in LC's observations 
Table 9: Sydney Park Observations: Thursday October 222020

Sydney Park Water Re-use Project: on-site observations

Thursday, Oct 22, 2020* from 10.15am-12noon

$S$ Kjaersgaard and C Evans, in three locations around the lower park

Overcast, soft breeze, temp around 68 degrees $F$

\begin{tabular}{|c|c|c|c|}
\hline Area & Adults & Kids & dogs \\
\hline Wetland Area 1 & 61 & 20 & 21 \\
\hline Wetland 4 (west side) * & NA & NA & NA \\
\hline Wetland 4 (East side) ${ }^{* *}$ & 56 & 5 & 28 \\
\hline Cascades/ Stepping stones & 63 & 6 & 28 \\
\hline TOTALS & 180 & 31 & 77 \\
\hline \multicolumn{4}{|c|}{$\begin{array}{l}\text { Main activity observed } \\
\text { - Walking and Running } \\
\text { Other activities observed*** } \\
\text { - Taking photos of the site, self, each other, of birds, artwork or site } \\
\text { - Intures. } \\
\text { - } 1 \text { person with disability. } \\
\text { - } 1 \text { person on scooters; } 1 \text { person on a skateboard. } \\
\text { Sitting: more prevalent in Wetland } 4 \text { area as there are tables and benches } \\
\text { provided here. }\end{array}$} \\
\hline
\end{tabular}

* Due to time constraints only Wetland 4 (East side) as observed on this day.

**B By this date in mid-Spring, perhaps a few more people retur ning to offices even part-time as COVID restrictions lightened up a bit. There appeared to be not quite as many visitors mid-week as a month earlier.

*** Specific counts for each of these activities not indicated as it doesn't really give us a picture of any dominant activities, other than walking/running ... and bringing the dog to the park. The case can be made that the addition of the pathway system through this area has enabled the walking/running, and the water bodies attract birds that also attract some interest, but that didn't appear to be a predominant activity in our observations.

\section{Sources:}

- Gehl Institute. no date. Using Public Life Tools: the complete guide. Copenhagen, New York and San Francisco: Gehl Institute. https://gehlpeople.com/tools/how-to-use-thepublic-life-tools/

- The data analysis for the survey was generated using Qualtrics software, Version [September 2020] of Qualtrics. Copyright @ (2021) Qualtrics. Qualtrics and all other Qualtrics product or service names are registered trademarks or trademarks of Qualtrics, Provo, UT, USA. https://www.qualtrics.comQualtrics XM.

- Erskineville 2043. (2020). "Erskineville 2043 Facebook Page." Facebook, September 28, 2020. https://www.facebook.com/groups/711277029259497

- Newtown 2042. (2020). "Newtown 2042 Facebook Page." Facebook, September 28, 2020. https://www.facebook.com/groups/Newtown2042 


\section{Limitations:}

The original research plan for Sydney Park included an intercept survey, in which individual park users would be randomly approached by a researcher and asked to answer a few questions about their visit to and activities in the park. However, restrictions on accessing public space during the early months of the COVID-19 pandemic prevented the team from undertaking that work. Had we been able to do this, the Gehl Institute's Public Life Data Protocol also has a "Participant Survey" tool that we would have used (https://gehlpeople.com/tools/participantsurvey/).

Our capacity to recruit respondents for the online survey meant we had to rely on distributing the survey via a social media platform, Facebook. Subsequently, the data we have gathered from the online questionnaire is not as rich as the intercept survey would have generated. Further, 21 survey responses are considerably fewer than we had aimed to receive.

COVID-19 restrictions limited our ability to interact with park users when we were able to be on site. When we were on-site we had limited time available to carry out the number of observations we'd originally intended.

Users were observed for only two days during September/October, which does not capture the full variation of the park users across seasons, particularly weekends and outside of COVID-19. We were not able to determine whether there was more or less use of the park because of the COVID-19 pandemic. During these months of restricted public access, people were predominantly working from home, and there was no data available to compare the observed activity against pre-COVID activity in the area of the water re-use project.

Because of the project's location within the greater Sydney Park site, it is difficult to differentiate in our observations between general park users and those who might be specifically drawn to the wetlands area of the site. This would have been determined in intercept surveys, had we been able to conduct them.

Enhances the public's awareness of the environmental aspects of the park as indicated by 84 posts on Instagram with a total of 4,430 'likes' related \#sydneyparkwetlands through August 2020. 64\% of 'likes' were generated for posts that identified the environmental elements of the project: $16 \%$ of those related to the water cascades and stepping stones; $11 \%$ related to "Water Falls"; 14\% related to the wetlands; and 23\% related to birds.

Improves the knowledge of environmental services for park users. $62 \%$ of 21 surveyed visitors reported that they understood the processes of water management because of the signage surrounding the wetlands and $48 \%$ reported that they visit Sydney Park primarily for the wetland.

\section{Method:}

We wanted to determine how effective the designed feature of the environmental artwork was at communicating the water story of the Sydney Park water-reuse project to the local community. 
We used two approaches to collecting the data, a content analysis of social media posts in Instagram, and a survey questionnaire.

\section{Social Media Content Analysis:}

Methods in social media analysis are relatively new (Kranz 2020), however calculating the total number of 'likes' deduces user engagement by determining the number of times people have affirmed posts related to specific content. We choose Instagram as the social media platform to understand how the park users engage with the wetland because the platform is heavily focused on the use of an image to communicate the way things look. Instagram is easy to use and is popular amongst a wide range of age groups. We used the hashtag \#sydneyparkwetlands to identify the sample size (84 posts). We tabulated the data from each post, by recording the date of the post, the user handle (source), the primary content or feature in the image, the complete suite of hashtags associated with the image, total number of comments and total number of likes.

\section{Table 10: Screenshot of tabulated Instagram posts}

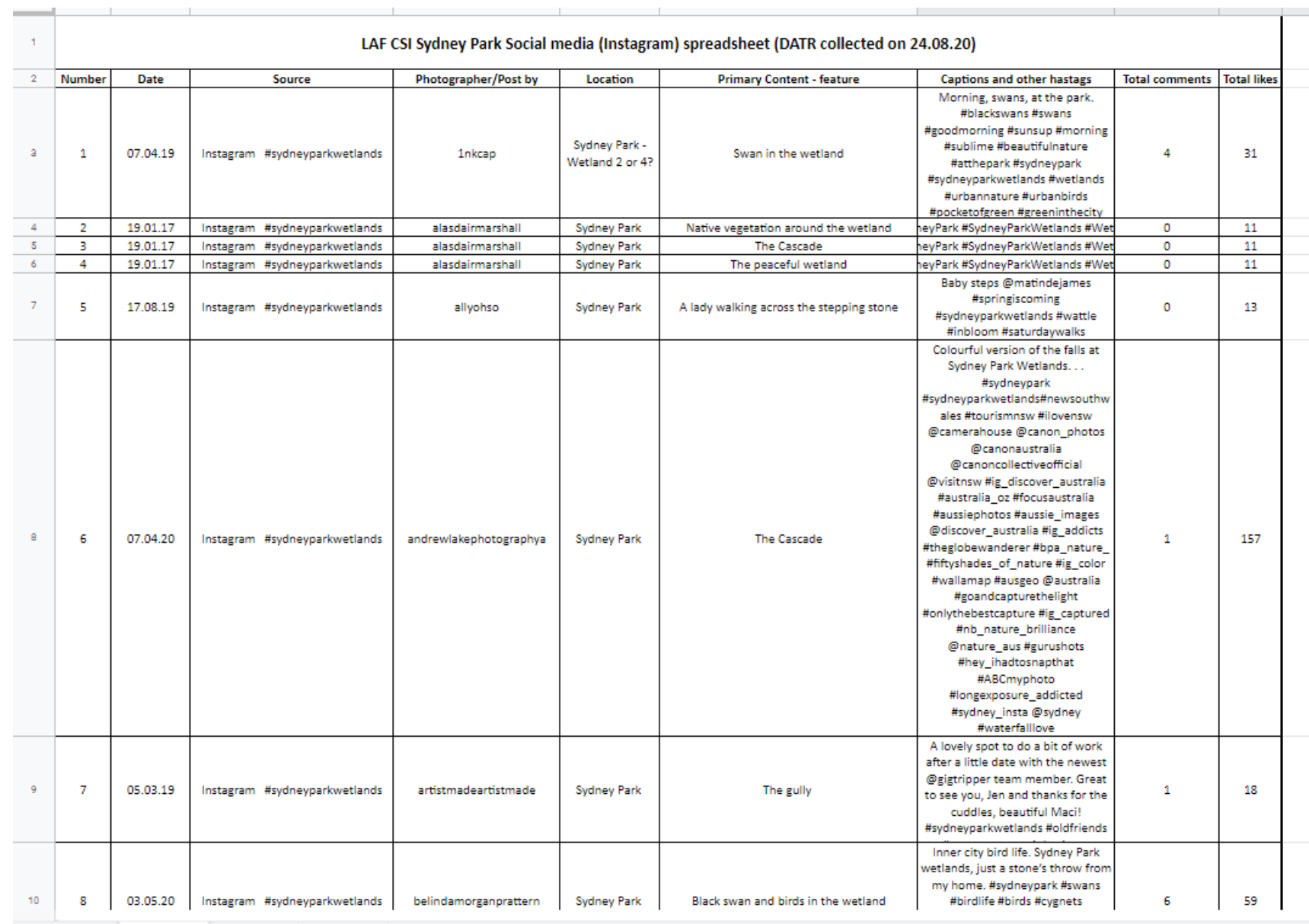

We then classified the data according to the recurring themes identified in the primary content/ feature column. The number of posts and likes was inputted and the overall percentage calculated. The ten themes identified in the 84 posts were: 
- Birds

- Stepping stones/cascades/gully

- Waterfalls and artwork

- Native vegetation

- Dogs

- Wetland

- Local government

- Sculpture (not waterfall artwork)

- Heritage

- Kids

\section{Calculation:}

For each of the themes identified in the social media content analysis, we performed a calculation of addition to determine the total number of likes across the 84 posts.

To determine the percentage, we used the $(n)$ value for each theme and divided this by the total number of likes $(4453) \times 100$. We rounded the percentage values to one decimal place. See Table 11.

Table 11: Classification of Instagram content into themes

\begin{tabular}{|l|l|l|l|}
\hline Theme: primary content/feature & Posts $(\mathbf{n})$ & Likes (n) & $\%$ \\
\hline Birds & 18 & 105 & 23.4 \\
\hline Cascades, stepping stones, gully & 16 & 729 & 16.4 \\
\hline Waterfalls and artwork & 16 & 478 & 10.7 \\
\hline Native vegetation & 4 & 162 & 3.6 \\
\hline Dogs & 6 & 1101 & 24.7 \\
\hline Wetland & 8 & 611 & 13.7 \\
\hline Local government & 1 & 30 & 0.7 \\
\hline Sculpture (not waterfall artwork) & 3 & 60 & 1.4 \\
\hline Heritage & 11 & 217 & 4.8 \\
\hline Kids & 2 & 23 & 0.5 \\
\hline Total number & $\mathbf{8 4}$ posts & $\mathbf{4 4 5 3}$ likes & \\
\hline
\end{tabular}




\section{Sources:}

- Kranz, Jeffrey, 2015. "7 Social Media Engagement Metrics for Tracking Followers and Growing Community." Buffer Blog (blog), September 21, 2015. https://buffer.com/resources/measure-social-media-engagement/\#likes-per-post

- Instagram (2010) https://instagram.com

\section{Limitations:}

- We chose to analyse the content of only one social media channel (Instagram) because of the licencing requirements with platforms (i.e. Tagboard) that calculate the results across a range of social media channels automatically. Because of this, it is possible that the data is limited, and might not express fully how the water reuse project has been communicated across social media.

- Of the 84 posts identified, six (6) of these posts, culminating in $25 \%$ of 'likes' related to the topic of dogs. However, only two (2) user handles were responsible for these six posts. One of these user handles has been created specifically as a 'dog account' (@lilywestie2008). This data skews the overall data-set because the 'likes' attributed to this post are because of the dog, not because of the \#sydneyparkwetlands.

- The calculations are taken from data up to and including the 24 August 2020. It is possible that impression numbers have increased against some of the posts since this date.

- There is potential for human error since there is no free platform and algorithm to filter through the posts for the criteria required for this method.

\section{Online Survey}

Qualtrics XM was used to analyze the data from the online questionnaire. The following data was collected and tabulated.

\section{Table 12: On-line survey questionnaire}

\begin{tabular}{|l|l|l|l|l|l|}
\hline Question & $\begin{array}{l}\text { Strongly } \\
\text { disagree }\end{array}$ & $\begin{array}{l}\text { Somewhat } \\
\text { disagree }\end{array}$ & $\begin{array}{l}\text { Neither } \\
\text { agree/disagre } \\
\text { e }\end{array}$ & $\begin{array}{l}\text { Somewhat } \\
\text { agree }\end{array}$ & $\begin{array}{l}\text { Strongly } \\
\text { agree }\end{array}$ \\
\hline $\begin{array}{l}\text { Q.1- I visit Sydney Park primarily to visit the } \\
\text { wetlands. }\end{array}$ & 1 & 3 & 7 & 10 & 0 \\
\hline $\begin{array}{l}\text { Q.2 I visit the wetlands (one a day; once a week; } \\
\text { several times a week; several times a month) }\end{array}$ & 4 & 4 & 4 & 5 & 4 \\
\hline Q.3 I visit the wetlands... & \multicolumn{3}{|l|}{$\begin{array}{l}\text { only during the week (4); only on the weekend (3); } \\
\text { during the week and on the weekends(14) }\end{array}$} \\
\hline Q.4 When I visit the wetlands I do so for... & \multicolumn{3}{|l|}{30 mins or less (5); 1hr or less(12); 1 hr or more(4) } \\
\hline Q.5 If/when I visit the wetlands I do so... \\
\multicolumn{5}{|l|}{$\begin{array}{l}\text { To relax on my own (2); to relax with others (1); to } \\
\text { watch the water features (0); to observe wildlife (0); } \\
\text { as part of my exercise routine (10); as part of my }\end{array}$} \\
\hline
\end{tabular}




\begin{tabular}{|l|l|l|l|l|l|l|}
\hline \multicolumn{5}{|l|}{\begin{tabular}{l}
\multicolumn{3}{|l|}{ child's outdoor activity (4); as part of my dogs } \\
exercise routine (6); other reason (1)
\end{tabular}} \\
\hline $\begin{array}{l}\text { Q.6 I am able to access as many areas around } \\
\text { the wetlands as I wish }\end{array}$ & 0 & 0 & 2 & 10 & 9 \\
\hline $\begin{array}{l}\text { Q.7 There are too many plants around the } \\
\text { wetland }\end{array}$ & 12 & 5 & 4 & 0 & 0 \\
\hline Q.8 There is enough shade around the wetlands & 0 & 4 & 9 & 6 & 2 \\
\hline $\begin{array}{l}\text { Q.9 The signage helps me understand the } \\
\text { process of water management in Sydney Park }\end{array}$ & 2 & 1 & 5 & 8 & 5 \\
\hline $\begin{array}{l}\text { Q.10 The signage helps me to understand the } \\
\text { needs and habits of different animals }\end{array}$ & 0 & 2 & 5 & 11 & 3 \\
\hline $\begin{array}{l}\text { Q.11 If I bought a visitor to Sydney Park, I would } \\
\text { make a point of showing them the water } \\
\text { cascades, stepping stones and water pipes. }\end{array}$ & 0 & 1 & 0 & 6 & 14 \\
\hline
\end{tabular}

Question 1 and 9 were used to determine the impact the water-reuse project had on people's understanding of the environmental services provided by the wetland.

For Question 1, 10 people out of 21 surveyed agreed with the question.

$10 / 21 \times 100=47.6 \%$ (we rounded this to the nearest whole number, $48 \%$ )

For Question 9, 13 people out of 21 surveyed agreed with the question.

$13 / 21 \times 100=61.9 \%$ (we rounded this to the nearest whole number, $62 \%$ )

We used Question 11 to determine how the environmental art work enhances the park users' experience by asking if they would make a point of showing the art work to a visitor. Six (6) people responded to the question as 'Somewhat agree', while 14 people responded 'Strongly agree'. A total of 20 people responded affirmatively to this question, representing $95 \%$ of the respondents. $(20 / 21 \times 100=95 \%)$.

\section{Cost Comparison}

The art installations and water features offer environmental and social value for Sydney Park users at a nominal construction cost, with the art installation of water cascades, stepping stones, and pipes adding only \$6 AUD per sf to the overall cost of the project. The overall cost of the project including the art installation was $\$ 11$ million AUD, and without the art installation the cost would have been \$10 million AUD. The art installation cost was $8.9 \%$ of the overall project and $12.6 \%$ of the landscape and amenity cost of the project. 


\section{Background:}

In a traditional engineered retrofit of a water cleaning and storage facility, the cost would be between AUD46.50 per square foot to AUD65 per square foot at the same design capacity. This compares to $\$ 65$ AUD per square foot for constructing the open landscaped bioretention areas in this project, including the cost of Turpin Crawford art installation (approximately AUD1 million total cost and $8.9 \%$ of the total project budget). However, this cost does not seem excessive compared to the cost of a traditional engineered retrofit water facility, especially given that the additional art installation brings additional environmental and social values to Sydney Park and its users (see Social Benefits above).

\section{Method:}

- Compare the average square feet rate to the square feet rate of Sydney Park with/without art installation cost

\section{Calculations:}

- Sydney Park Water Re-use Project total costs AUD11.2 million for a total 172,062 sf area.

- The cost of Turpin-Crawford's art installation: AUD1 million

Sydney Park water reuse project with Turpin-Crawford art installation square feet rate:

- The average square feet rate: AUD11,200,000 / 172,062 sf = AUD65 / sf

If the Sydney Park water reuse project had been constructed without the Turpin-Crawford art installation square feet rate:

- The average square feet rate: AUD10,200,000 / 172,062 sf = AUD59 / sf

\section{Sources:}

- Knights, D., Beharrel, D. \& Jonasson, J. (2010). What does it cost to build a water quality treatment system? Conference Proceedings of the 2010 National Conference of the Stormwater Industry Association. Available at https://www.equatica.com.au/pdf/Knights,\%20David\%20et\%20al\%202010.pdf

- Taylor, A., Leinster, S., \& Allison, R. (2010). National needs analysis: Life cycle costing data and tools for water sensitive urban design Assets. Prepared for WSUD Program, Sydney Metropolitan Catchment Management Authority. Available at https://www.clearwatervic.com.au/user-data/resource-files/Final-LCC-report-9November-2010[1].pdf

\section{Limitations:}

- The costs may be out of date. 


\section{Inconclusive Benefits}

We considered a number of economic benefits for this case study. We were particularly interested in assessing any cost savings related to the water treatment processes and the reduced reliance on potable water. However our work with the City of Sydney revealed that the economic efficiencies and benefits were less important than the social and environmental outcomes. Our research bears this out--the social and environmental outcomes are clear and data readily available, while accessing relevant and reliable evidence in relation to economic benefits proved to be beyond our scope for this project. 